\title{
Postcolonial Realities in Chimamanda Ngozi Adichie's 'Ghost 'in the Thing around Your Neck
}

\author{
Japheth Peter Muindu* \\ Department of Arts and Social Sciences Garissa University, P.O.Box 1801, Garissa
}

*Corresponding Authors: Japheth Peter Muindu, Department of Arts and Social Sciences Garissa University, P.O.Box 1801, Garissa

\begin{abstract}
This paper is an analysis of Chimamanda Ngozi Adichie short story, 'Ghost' in her anthology The Thing around Your Neck which utilizes Achille Mbembe's ideas of the postcolony to analyze the representation of postcolonial realities in Nigeria. Postcolonial theory is an epistemological frame of reference which enables a critique of institutions and practices and unmasks exploitative and discriminative structures. The theory challenges neocolonial realities which are consequences of colonialism and is therefore germane to the analysis of the mediation of the postcolonial condition in the Nigerian society in the short story under study. These postcolonial realities have the net effect of engendering alienation to the masses who suffocate under misrule and dominance. The setting and the plot of the story captures this neocolonial condition in Nigeria and a postcolonial analysis of the story will provide an insightful reading.
\end{abstract}

Keywords: Postcoloniality, Realities, Corruption, Alienation

\section{INTRODUCTION}

Chimamanda Ngozi Adichie was born in 1977 in Enugu, Nigeria. She grew up in the university town of Nsukka where both her parents where employees of the university. She is an acclaimed author anda public intellectual with remarkable artistic outputs. The United States, but who revisits Nigeria, her home country, for the plots of most of her fiction. Her literary oeuvre includes Purple Hibiscus, Half of a Yellow Sun, Americana, and a volume of short stories anthologized in The Thing around Your Neck. Her fiction reveals her critical engagement with diaspora issues, feminism and postcolonial problems.

\section{MATERIALS AND METHODS}

Adichie's short story 'Ghost', anthologized in The Thing around Your Neck, speaks to the socialeconomic and political problems bedeviling post-independence Nigeria. The paper focuses on how she articulates these neocolonial realities through the configurations of her characters and the use of other rhetorical devices. The paper is a critical reflection on the dystopian elements in the selected short story through Mbembean lenses, especially his postulation of the postcolonial forms of power.

\section{RESULTS AND DISCUSSION}

Adichie's short story 'Ghost' alludes to the 1967-1970 Biafra War in Nigeria which she deploys as a pivotal vantage point to scan the realities of postcolonial Nigerian state. The plot of the story unfolds through the narrative voice of Professor James Nwoye, a retired 71-year-old Mathematics professor who was at Nsukka University at the time it fell to the federal forces during the civil war. The protagonist in the story epitomizes the devastation of the war, having lost a child to it and suffered disruption and dislocation.

'Ghost' focuses on the present but flashes back to the past to reveal the harsh realities of the fictional postcolonial spaces it recreates. 'Ghost' is a fictional reminiscence of Biafra war in Nigeria which unfolds through the eyes of Prof. James Nwoye, a retired mathematics professor who fled Nigeria at the time of civil upheavals and who came back to take up his appointment as a professor at Nzukha university after the war ended. When the story opens, he has visited the university to pursue his pension which has delayed for three years after his retirement. 
Despondency is palpable in the faces of the hapless pensioners who have become accustomed to these disappointments. Corruption is so pervasive in the postcolonial polity of the story that the pensioners speculate that the pension has delayed because the education minister has pilfered the money. Others speculate that the Vice-Chancellor has deposited the money in high-interest personal accounts. They curse the Vice-Chancellor in obscene expletives. 'Let his penis quench, he will die of diarrhea. His children will not have children. (p.50)[2].These expletives are evocative of the Bakhtinian grotesque as the hapless citizens turn to outburst of ribaldry and derision to hold the oppressive polity in ridicule. For Bakhtin:

indent highlighted quotation from Bakhtin starting are above all the province of ordinary people.... a means of resistance to the dominant culture, and as a refuge from it, obscenity and the grotesque are parodies which undermine officialdom by showing how arbitrary and vulnerable is officialese and turning it all into an object of ridicule (Mbembe, 1992:4)[1]

One obvious dystopian element is the reality of session from the repressive central government, the historical reality of Biafra war which is recreated in the story, and in which the dissatisfied Easterners seceded to declare the state of Biafra. To extrapolate from history:

...on 30 May 1967 Ojukwu proclaimed the secession of the southeast of Nigeria as the republic of Biafra.... The Nigerian government did not recognize this new republic, however, and the Nigeria-Biafra War began in July. Even though the Biafran troops were outnumbered, and had a shortage of weapons, they managed to achieve some wins in the beginning of the war. However, with the support of the United Kingdom and the USSR, the federal troops encircled the area, and blocked all of Biafra's links to the outside world. This led to a great shortage of means and food; it is estimated that up to three million people died in Biafra, mostly from starvation. Ojukwu fled, and Biafra surrendered to the federal troops on January 13 1970. The violence between the different ethnic groups, however, continued after this. Even though the ethnic tensions are still a part of the Nigerian reality today, their intensity has lessened somewhat over the last decades (Mey.J, 2011:5) [1]

The civil war engendered a political paralysis in the Nigerian polity and led to the fragmentation of the state. The story chronicles elements of political stasis characterized by killing of intellectuals and their forced exile to European metropolis. It also recreates the trauma of the civil strife in which characters like Prof. Nwoye and Mr. Ikene Okoro lost their kin to the war. In the textualization of the history of Biafra civil strife in Nigeria, Adichie's short story 'Ghost' recreates the death of the iconic poet Christopher Okgibo, who was killed in the civil war. The Nigerian postcolony has been militarized as seen in the brutality of federal soldiers as they invade Nsukka University. This scenario is quintessential of a postcolony which is, according to Achille Mbembe:

characterized by a distinctive style of political improvisation, by a tendency to excess and a lack of proportion as well as by distinctive ways in which identities are multiplied, transformed and put into circulation...the postcolony is also made up of a series of corporate institutions and a political machinery which, once they are in place, constitute a distinctive regime of violence (Mbembe, 1992:1) [1]

The story gives a snapshot of graft in Nzukka University to paint the grim picture of postcolonial debacle. Nzukka university lecturers are packaged as a pack of inept and aggrandized greenhorns who have run down the institution. IkenaOkoro laments:

Nobody is teaching. Nobody has fresh ideas. It is university politics, politics, while students buy grades with money or their bodies. Senate meetings have become personality cult battles (p.68) [2]

The university is mired in mediocrity of proportional levels as a result of biased appointments of incompetent Vice-Chancellors, one of whom is Professor Udeama who had been the university ViceChancellor for eight years and whose incompetence is satirized in the story by enumerating his mundane credentials instead of his academic qualification. That it is highlighted he was the best ball room dancer in the university and nothing is said about his academic credentials passes him as a political appointee not fit for purpose. It is no wonder that the university is run down under his watch. 
This is a characteristic of a postcolony, where, as Mbembe aptly observes, in regard to Cameroon postcolony:

To ensure the reproduction of such an economy of pleasure, posts and palaces and public places have been filled with a large number of buffoons, fools and clowns at various levels, offering a variety of services-journalists, insiders, clerks, hagiographers, censors, informers, Party hacks expert in eliciting vote confidence, praise singers of any kind, courtiers, intellectuals in search of an official perch, middlemen . . . (Mbembe, 1992:2)[1]

In the narrative discourse of the story, a lot of money has been siphoned through fraudulent purchase of cars which are stamped with names of fictitious foreign foundations. Most of the people involved in such heist are arraigned in court only to be released scot free presumably because they are politically correct. Things are not ameliorated by the change of guard since even the current VC perpetuates the same culture of pilfering from the university coffers. There are accusations of bribery in the pension office where lecturers circumvent retirement by bribing to have their records changed. The rot in the university is so disturbingly debilitating that the university can be read as a microcosm of the entire society where graft obtains.

There is a pervasive mood of despair and despondency symbolized by images of ruin and desolation, such as the description of the university campus as 'a withered skin of what it used to be' (p.70) [1]. The story contrasts this despondency with the inauthentic and artificial life in America where, unlike his daughter Nkiru, who has come to terms with her diasporic identity in America, Prof Nwoye is resigned to his predicament as a postcolonial subject in Nigeria.

The media exposes the scandal of fake drugs sold by unscrupulous businessmen which the story presents as an indictment of the materialism and indifference that characterize the capitalistic economy of the past-independent Nigerian society mediated in the story. It is compellingly traumatic that Ebere, Professor James Nwoye's wife, lost her life because she was given fake drugs during her ministration in a government facility. The story utilizes this narrative event to present the trauma of loss by narrating the reappearance of Ebere as aghost (one of the ghosts of the title) who intrudes into Nwoye's presence as if she has not died. In what verges on magical realism, Adichie reincarnates Ebere to stage the trauma of lose in the wake of Biafra war. Adichie lets Prof. Nwoye remark that he stopped going to church after Ebere started visiting as a ghost, reasoning that this appearance brought a sense of metaphysical certainty lack of which compels people to believe in the afterlife. Prof. Nwoye's absurdist and skeptical view of religion in this narrative event bespeaks of Adichie's ambiguous spiritual outlook and her ambivalent relationship with Catholic faith. She confesses her struggle with faith thus:

I find that I am interested in the idea of faith, but I don't know if I have faith. There are times when I am certain that I will never believe in anything, and there are other times when I find this odd longing and I think there has to be something (cited in Tunca, D, and 2013:67)[5]

Presumably, this ambivalence emanates from her awareness of the disharmony between delusionary religiosity and the postcolonial atrocities that are rife in her Nigerian society. Prof. Nwoye's absurdity is reinforced, rather than mitigated, by the insertion of vulgarity into the narrative:

Sometimes when she visits, she tickles my testicles, her figures running over them. She knows very well that my prostrate medication has deadened things down there, and she does this only to tease me, to laugh her gently jeering laugh'(p.72)[1]

This dark humour offers comic relief from the alienating realities mediated in the story and at the same time eases the trauma of Prof. Nwoye's bereavement. Prof. Nwoye's sterility mentioned here is both individual and collective, a metaphor of the sterility and fragmentation in the postcolonial Nigerian nation-state.

This prebendalization of the state has precipitated hostility and resistance as can be seen in the resistance rhetoric championed by the firebrand social scientist, Ikenna Okoro, who was admired by his colleagues for the 'erudite asperity' with which he 'blazed through issues' (p.61) [2].Though he has lost stamina as a result of enervating neocolonial realities, he is insistent that something has to be done to tame the disabling political malfeasance that define postcolonial Nigeria. He was so gallantly confrontational in his attack on the government that he was believed to be one of the dissidents killed 
at Nsukka when the university fell to the renegades since he had been seen driving towards the place instead of fleeing from it. Nwoye is uncertain he wasn't seeing Ikenna Okoro apparition when he encountered him at the University Bursary Building, (he is another ghost of the title).In the story, the image of the ghost is a structuring metaphor which enables the writer to reconstruct the ghosts of Biafra war and to demonstrate how the political body of postcolonial Nigeria is continuously shaped and immersed in this atrocious historicity.

\section{CONCLuSion}

In her representation of postcolonial realities in this story, Chimamanda Ngozi Adichie emerges as an African short story writer, who, like the African novelist, is a writer in politics, concerned as she is with repression in the Nigerian postcolonial state. Her short story urges a political consciousness and an urgent need to foster a more egalitarian politics.

\section{REFERENCES}

[1] C.Adichie, the Thing around Your Neck, Lagos, Nigeria: Farafina, 2009

[2] A.Mbembe, Provisional Notes on the Postcolony in the Journal of the International African Institute, 1(62), 1992, pp. 3-37

[3] Mey, J D, The Intersection of History, Literature and Trauma in Chimamanda Ngozi Adichie Half of a Yellow Sun, Unpublished MA Thesis, Gent University, (2011)

[4] D,Tunca, 'The Confessions of a Buddhist Catholic: Religion in the Works of Chimamanda Ngozi Adichie' in Research in African Literatures 3(44), 2013, pp.50-71

\section{AUTHOR's BIOGRAPHY}

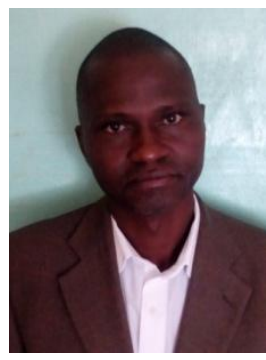

Dr. Japheth Peter Muindu, is a senior lecturer in the department of Arts and Social Sciences at Garissa University, Kenya. He holds a philosophical doctorate in Literature. His research interest is in popular fiction, postcolonial studies, gender studies and medical humanities.

Citation: Japheth Peter Muindu. "Postcolonial Realities in Chimamanda Ngozi Adichie's 'Ghost 'in the Thing around Your Neck" International Journal on Studies in English Language and Literature (IJSELL), vol 8, no. 5, 2020, pp. 26-29. doi: http://dx.doi.org/10.20431/2347-3134.0805002.

Copyright: (C) 2020 Authors. This is an open-access article distributed under the terms of the Creative Commons Attribution License, which permits unrestricted use, distribution, and reproduction in any medium, provided the original author and source are credited. 